\title{
Antikoagulantna terapija u preoperativnoj pripremi bolesnica sa oboljenjima ginekoloških organa
}

\author{
Đorđević Spomenka, Berisavac Milica
}

Institut za ginekologiju i akušerstvo Klinički centar Srbije, Beograd

\begin{abstract}
Abstrakt
Sposobnost organizma da zaustavi krvarenje iz oštećenog krvnog suda je neophoda za preživljavanje pacijenta.Isto tako,veliki uticaj ima i sposobnost organizma u regulisanju različitih procesa u koagulaciji krvi,čime se može sprečiti nastanak tromboza i mogućih fatalnih posledica. U zdravom organizmu postoji ravnoteža prokoagulantnih i antikoagulantnih faktora hemostaze i pod normalnim okolnostima sistem funkcioniše u korist prevage antikoagulacije Hirurške procedure u tretmanu bolesti ginekološkh organa nose veliki rizik za nastanak dubokih venskih tromboza, imajući u vidu anatomske odnose u maloj karlici i bogatu vaskularizaciju obturatornih i ilijačnih jama.Standarna terapijska doza heparina niske molekulske mase (LMWH) sa ciljem prevencije nastanka venskih tromboza, a u slučajevima blagog i umerenog rizika je 3.000-5.000U/24 h.U svim slučajevima visokog rizika, doza niskomolekulskog heparina se može udvostručiti . Veća sklonost ka nastanku dubokih venskih tromboza u svakoj hirurškoj proceduri u maloj karlici naročito kod ženske populacije, stavlja primenu heparina niske molekulske mase kao primarni cilj u prevenciji eventualne tromboembolijske bolesti.
\end{abstract}

Ključne reči: preoperativna priprema, duboka venska tromboza, heparin niske molekulske mase

Sposobnost organizma da zaustavi krvarenje iz oštećenog krvnog suda je neophoda za preživljavanje pacijenta.Isto tako,veliki uticaj ima i sposobnost organizma u regulisanju različitih procesa u koagulaciji krvi,čime se može sprečiti nastanak tromboza i mogućih fatalnih posledica.Hemostazni sistem ima značajnu fiziološku ulogu da održava krv u tečnom stanju unutar vaskularnog sistema ${ }^{1}$. Hemostaza se odvija u četiri faze:

1. vaskularna faza u kojoj oštećenje krvnog suda dovodi do kontrakcije ćelija glatkih mišića na mestu lezije .

2. trombocitna faza započinje adhezijom trombocita na mestu oštećenog endotela i započinjanjem procesa agregacije u kojima značajnu ulogu ima fibrinogen.Aktivacija trombocita se odvija pod dejstvom različitih faktora i na mestu lezije se stvara trombocitni čep.

3. faza koagulacije krvi nastaje procesom kaskadne aktivacije faktora zgrušavanja ,pri čemu nastaje trombin,kao najznačajniji enzim koagulacionog sistema.Trombin deluje na rastvorljivi protein plazme, fibrinogen i konvertuje ga u nerastvorljivi fibrin.Stvorena fibrinska mreža u kojoj su trombociti (beli koagulum) i eritrociti (crveni koagulum) obuhvata trombocitni čep i zaustavlja krvavljenje.

4. fibrinoliza predstavlja proces razlaganja koaguluma pod dejstvom enzima plazmina,čime se omogućava ponovno uspostavljanje normalnog protoka krvi.Sam proces fibrinolize je značajan regulatorni mehanizam koji sprečava prekomerni rast koaguluma.

U zdravom organizmu postoji ravnoteža prokoagulantnih i antikoagulantnih faktora hemostaze i pod normalnim okolnostima sistem funkcioniše u korist prevage antikoagulacije.Ako dominiraju antikoagulantni faktori (napr.trombocitopenija) javlja se krvavljenje.U slučaju preovladjivanja prokoagulantnih faktora, dolazi do tromboze ${ }^{2}$.

Od velikog je značaja načiniti razliku izmedju hemostaze i tromboze.Hemostaza predstavlja zaštitni mehanizam organizma od prekomernog gubitka krvi u oštećenom krvnom sudu.Hemostatski tromb je beli tromb i ne ometa normalan protok krvi.

Tromboza je proces koji se odvija u neoštećenom krvnom sudu,gde agregacija trombocita i/ili nakupljanje fibrina dovodi do potpune obliteracije krvnog suda.Formiranje tromba u venskim sudovima može dovesti 
do kompletne obliteracije čime nastupa prekid odliva krvi iz odredjenih delova organizma.Ispod mesta okluzije dolazi do zastoja krvi,inflamacije tkiva i stvaranja edema.Obzirom da formirani tromb nije kompaktne strukture,svaka promena položaja ili promena pritiska unutar krvnih sudova može dovesti do odvajanja delova tromba,koji nošeni krvnom strujom mogu dospeti i do plućaAko je embolus dovoljno veliki može dovesti do obliteracije plućne arterije i dati znake masivne embolije sa često fatalnim ishodom ${ }^{3}$.

Hirurške procedure u tretmanu bolesti ginekološkh organa nose veliki rizik za nastanak dubokih venskih tromboza, imajući u vidu anatomske odnose u maloj karlici i bogatu vaskularizaciju obturatornih i ilijačnih jama.Standarna terapijska doza heparina niske molekulske mase (LMWH) sa ciljem prevencije nastanka venskih tromboza, a u slučajevima blagog i umerenog rizika je 3.000-5.000U/24 h.U svim slučajevima visokog rizika, doza niskomolekulskog heparina se može udvostručiti ${ }^{4}$.

Sama primena nefrakcionisanog heparina mora trajati što kraće zbog rizika od pojave Heparinom Indukovane Trombocitopenije (HIT),svakako najtežom komplikacijom antikoagulantnog postupka lečenja bolesnika. I upotreba heparina niske molekulske mase može dovesti do HIT , ali znatno redje,jer su njegove molekule manje imunogene.Kada se postigne terapijski efekat date terapije,neophodno je započeti oralnu antikoagulantnu terapiju u svim onim slučajevima gde je to neophodno.Cilj postignutog terapijskog učinka je opseg INR izmedju 2 i 3.

U preoperativnim pripremama bolesnica sa oboljenjima ginekoloških organa u širokoj su primeni heparini niske molekulske mase u cilju profilakse venskih tromboza .Prednost primene ovih lekove je stabilniji farmakokinetski profil i mogućnost doziranja prema telesnoj masi, bez kontinuiranog laboratorijskog praćenja aPTT-a. I pored značajnih prednosti u prevenciji venskih tromboza heparina niske molekulske mase, neophodno je napomenuti da se za lečenje masivnih embolija pluća i dalje primenjuje iv heparin.Antikoagulantno dejstvo heparina ostvaruje se indirektno preko antitrombina (AT).Antitrombin se sintetiše u jetri, cirkuliše plazmom i vrši inhibiciju trombina, FXa (anti Xa) i FIXa.Lanac heparina je dovoljno dugačak što omogućava istovremeno vezivanje i antitrombina i trombina,dok su lanci heparina niske molekulske mase kraći , pa je njihovo antikoagulantno dejstvo vezano za inhibiciju FXa preko antitrombina.Bitno je napomenuti da se heparin ne resorbuje preko digestivnog trakta, a za vreme davanja antikoagulantne terapije treba izbegavati muskularne aplikacije lekova,zbog mogućih pojava masivnih i teških krvavljenja ${ }^{5}$.

Sklonost ka krvavljenju prilikom primene antikoagulantne terapije se može pojaviti u bilo kom momentu od započinjanja terapije heparinom, čak i kada je aPTT u okviru referentnih vrednosti, ali znantno češće ukoliko je aPTT produžen.Veći rizik za pojavu krvavljenje imaju osobe starijeg životnog doba,ulkusni bolesnici,i osobe koje se podvrgavaju hirurškoj intervenciji.Brza neutralizacija heparina sprovodi se davanjem protamin sulfata u dozi od $1 \mathrm{mg}$ na svakih 100 jedinica datog heparina.Protamin sulfat neutralizuje i antitrombinsko dejstvo heparina niske molekulske mase.

Imajući u vidu mnoge neželjene efekte i moguće komplikacije prilikom primene nefrakcionisanog heparina, indikaciono područje za njihovu primenu je dosta redukovano.Heparini niske molekulske mase su zamenili nefrakcionirani heparin i osvojili veliki broj kliničkih stanja i potreba, dok su brojne studije dokazale da je podjednako efikasan, a bezbedniji za primenu.Subkutana administracija leka na $24 \mathrm{~h}$ ili $12 \mathrm{~h}$,bez potrebe kontinuiranog praćenja laboratorijskih parametara terapijskog učinka su konforan način primene antikoagulantne terapije ${ }^{6}$.

Treba naglasiti da je primena heparina niske molekulske mase lek izbora u tretmanu trombofilije prouzrokovane postojanjem lupus antikoagulansa ,koja se dijagnostikuje kod skoro trećine bolesnika sa nekim autoimunim oboljenjem.

Doziranje antikoagulantne terapije je strogo individualno sa brižljivom procenom rizika kako od nastanka tromboembolijskih komplikacija, tako i od moguće pojave krvavljenje. Poseban oprez je neophodan kod osoba sa oštećenom bubrežnom funkcijom,jer u takvim slučajevima izlučivanje heparina iz organizma može biti smanjeno.

Širok spektar ginekoloških stanja koja zahtevaju primenu neke operativne procedure predstavljaju veliko indikaciono područje za adekvatnu preoperativnu pripremu,koja svakako uključuje i primenu antikoagulantne terapije.Manje hirurške intervencije u okviru vaginalne hirurgije ne zahtevaju profilaktičko davanje heparina niske molekulske mase, sem u slučajevima definisanog rizika(predhodne anamneze o venskim trombozama 
ili izraženim varikozitetima).Primena heparina niske molekulske mase je neophodna u svakoj pelvičnoj hirurgiji, a doza antikoagulantne terapije odredjuje se strogo individualno ${ }^{7}$.

Kategorizacijom rizika u hirurškim intervencijama , a u skladu preporuke za profilaksu dubokih venskih tromboza (DVT) konstatuje se povišena šansa u životnom dobu preko 40-te godine, a abdominalna hirurgija i ginekološki maligniteti nose dodatno visok rizik javljanja DVT.

Veća sklonost ka nastanku dubokih venskih tromboza u svakoj hirurškoj proceduri u maloj karlici naročito kod ženske populacije, stavlja primenu heparina niske molekulske mase kao primarni cilj u prevenciji eventualne tromboembolijske bolesti.Hirurška trauma, obimnost i radikalnost hirurških zahvata,aktuelni gubitak krvi, naročito kod malignih bolesti ženskih genitalnih organa nameće multidisciplinarni pristup i adekvatnu preoperativnu pripremu, uz adekvatno praćenje postoperativnog toka, kako bi se rizik nastanka dubokih venskih tromboza ili embolizacije, smanjio na najmanju moguću meru.

Principi primene profilktičke antikoagulantne terapije zasnivaju se na preporukama radne grupe za antitromboznu terpiju Američkog udruženja pulmologa (ACCP) iz 2004,kao i terapijske doze za lečenje dubokih venskih tromboza ili sumnje na postojanje dubokih venskih tromboza .U navedenim preporukama prednost se daje heparinu niske molekulske mase, sem u slučajevima masivne embolizacije.

Heparini niske molekulske mase koji se koriste u profilaksi tromboembolijske bolesti imaju stabilni antikoagulantni efekat,pa ih to čini izuzetno prihvatljivim i u lečenju DVT. Hemijskom i enzimskom polimerizacijom dobijeni su od nefrakcioniranog heparina ,što im daje različite farmakološke osobine, ali isto tako i brojne prednosti u odnosu na standardni heparin.

\section{Literatura}

1. Aird WC.Natural cogulation inhibitors:activated protein C.Best Pract Res Clin Haematol 2004;17:161-82

2. Samama MM, Desnoyers P,Gerotziafas GT.Low Molecular Weight Heparins:a Comparative rewiew of pharmacodinamic,clinical pharmacology.Clinical and laboratory Aspectts of Thromboembolic Disease,8th Advanced Teaching Course in Thrombosis and Haemostasis 2001,Proceedings;71-96

3. Ginsberg JA, Crowther MA, White RH, Ortel TL. Antocoagulation Therapy. Haematology 2001;339-57

4. Buller $\mathrm{H}$ et all.Antithrombotic therapy for venous thromboembolic disease.Chest 2004; $126: 401 \mathrm{~S}-28 \mathrm{~S}$

5. Kenneth W, Matijevic-Aleksić N.Molecular aspects of thrombosis and antithrombotic drugs.Critical Reviews in Clinical Laboratory sciences 2005;42(3):249-77

6. Kakkar AK.Low and ultra-low-molecular-weight heparins.Best Pract Res Clin Haematol 2004;17:77-87

7. Čolović R, Čolović M.Venski tromboembolizam u hirurgiji,Beograd 2000;131-47 